\title{
On Ancient Mixed Masonry of Brick and Stone
}

\section{H. Bloxam}

To cite this article: M. H. Bloxam (1844) On Ancient Mixed Masonry of Brick and Stone, Archaeological Journal, 1:1, 307-317, DOI: 10.1080/00665983.1844.10850533

To link to this article: http://dx.doi.org/10.1080/00665983.1844.10850533

曲 Published online: 10 Jul 2014.

Submit your article to this journal $\pi$

III Article views: 1

Q View related articles $\sqsubset$ 
Soche a cyte was noone undur sonne, Hyt was never nor schalle be wonne.

Ther be abowte syxty gatys y-wys,

And .ij. brygges and .ij. portcolys;

Ovyr the watur ys a brygge of brasse,

Man and beste ther-ovyr to passe;

Whan ony bestys there-over gone,

Os bellys ryngyng faryth hyt thane.

At the brygge ende stondyth $a$ towre,

Peyntyd wyth golde and asewre;

The toret was of precyus stonys,

Ryche and gode for the nonys.

T. WRIGHT.

\section{ON ANCIENT MIXED MASONRY OF BRICK AND STONE.}

THE specimens of ancient masonry we meet with in this country, of a date anterior to the thirteenth century, exhibit such a diversity of construction as to lead to the inquiry, whether there are any decided marks of discrimination which we may apply so as to affix to each its proper epoch and character, whether as belonging to the ancient British, the Roman, the Anglo-Saxon, or Anglo-Norman era.

It is doubtful whether we have any remains of early masonry to evince that, prior to the Roman invasion, the use of lime in a calcined state mixed with water and sand, or any other substance, so as to form an adhesive cement by which stone could be joined to stone, was known to the ancient inhabitants of this island. On the contrary, in most of the existing remains of ancient British masonry, or those which may be presumed to be such; in the stone walls with which some of the fortified posts of the Britons are surrounded, or nearly so ; in the vestiges of their huts or dwellings, which are still in some places apparent; in their structures of a sepulchral class formed of large and irregular-shaped stones, such as the cromlechs, where one huge flat but irregular-shaped stone is raised in an inclining or horizontal position on the points or edges of other large and 
irregular-shaped stones placed on edge, by means of which a rude chamber is formed; or the cistvaens constructed in like manner, whether found singly or in a continuous range of cells with a rude passage between each to connect them, the whole being composed of stones set on edge supporting other flat stones as a roof or covering and then coated over with earth : we find a total absence of any thing like mortar or cement. Even at Stonehenge, where the stones have been worked by the tool, where the trilithons exhibit the mortice and tenon, and could only have been upraised by mechanical force of considerable power, no traces of cement or mortar are visible. If there is any instance in which the existence of masonry cemented with lime occurs in this country before the Romans formed a settlement within it, such was an exception to the general rule.

On the summit of Worle Hill near Weston-super-Mare, Somersetshire, very extensive remains of ancient British masonry are visible. This hill forms a ridge about three miles in length, the western point projects like a promontory into the Bristol channel, and this point is cut off from the remainder of the hill by a series of sunk ditches, and two stone walls, one behind the other in parallel lines crossing the hill from north to south, and these walls are continued along the southern face of the summit of the hill in a westerly direction, and in other parts where the declivity of the face of this part of the hill is not formed by a precipitous rock, as it is in great measure on the north side.

It is very difficult to ascertain from the present appearance of this walling its original height or breadth : exposed to the storms of centuries acting on a bleak and elevated situation, and composed of loose stones without mortar, this rude masonry, if so it may be called, now presents the appearance of a ruinous rampart or bank of irregular-shaped stones; for the upper part of the wall having been displaced and thrown down, either by human violence, or by the natural force of the winds, or probably by both, the base is increased in width whilst the height is diminished, and the original masonry of the lower part of the wall is concealed by the stones thus ejected from the upper part, so that in one part the stones cover the base to the extent of sixty feet in breadth, and the bank now rises to the height of ten or fifteen feet externally, and to the height of five or six feet internally. Here and there 
however the loose stones having been cleared away, the masonry of the wall is visible, and this discloses a regular surface or flat facing of irregular-shaped stones put together without mortar, few of the stones being larger than what a man might lift, and, as far as can be judged, the thickness of the walls thus constructed may be from eight to ten feet.

Within the area inclosed by these walls is a space of about twenty acres, this has been planted with trees, and in the course of a few years many interesting features will be obliterated, or nearly so, but at present numerous small pit-like cavities or excavations of a circular form are visible, most of them no more than from five to six feet in diameter, though some are of a larger size. Many of these are now filled with stones, and there is, I think, little doubt but that these cavities are the sites of the huts of the ancient Britons, and that the stones with which they are filled are those of the walls; whilst this apparent reason may be assigned for the formation of these cavities, that they served as a protection from the cold and bitter winds of the wintry storms to which this elevated site was much exposed.

Some of these excavations are nine or ten feet in diameter, and in some places there appears to have been a continuous range or cluster of huts, or one much larger than usual, and in one place on the south-east side of this inclosed area is a space, whether of a circular or square form can now with difficulty be ascertained, sixteen or eighteen feet square or in diameter. In one part are the apparent remains of the walls of one of these huts standing to the height of eighteen inches or two feet; these walls are eighteen inches in thickness, constructed of stones, mostly small, piled one above another, inclosing a space not more than four feet six inches long by four feet wide. Some of the excavations are not filled up with stones, and some of the stones seem to have undergone the action of fire.

The whole of these remains are worthy of a more minute examination than that which, in the course of a recent and hurried visit, I was able to bestow upon them.

In the Munimenta Antiqua, remains and traces of what are supposed to have been the ancient dwellings of the Britons, very similar to those at Worle Hill, are enumerated as existing in several places in the Isle of Anglesey, in Caernarvonshire, in Cornwall, and elsewhere; remains also of ancient British 
masonry, or dry stone walls without mortar, similar to those on Worle Hill, are described as the ramparts round many ancient British fastnesses, as at Caer Bran Chun castle, and castle An Dinas in Cornwall ${ }^{a}$; and this kind of masonry agrees with the description given by Tacitus, who describes the Britons under Caractacus as occupying fortified posts situated on steep mountains, and that wherever the access was easy he blocked it up with stones like a wallb, and Strabo describes the huts of the Gauls as being of a circular form.

The remains of this supposed ancient British masonry are yet considerable, and in the works of Rowland, Pennant, Borlase, and King, we have the position of several described and pointed out. On a more minute investigation and comparison than has perhaps yet been exercised, there may be found in these remains some peculiarities or features of construction which have not hitherto been noticed. It is a point of Archæology on which the field is still open for research.

That the Romans after they had obtained a permanent settlement in this country soon commenced the construction of public edifices, is evident from the notice taken by Tacitus of the temple of Claudius at Camalodunum, when that colony was attacked and the temple destroyed in the revolt of the Britons under Boadicea.

But of the numerous structures, both of a public and private nature, erected by the Romans during the four centuries of their occupancy of this island, we have, notwithstanding their gradual demolition and destruction during fourteen centuries, ample vestiges remaining, though not in an entire state, to shew their peculiar masonry and construction.

These remains consist principally of walled inclosures or fortified posts, such as those at Richborough and Pevensey: of fragments of public edifices, as at Leicester and Wroxeter: of the walls of their cities, of which remains exist at St. Alban's, York, Lincoln, and Silchester : of towers, such as that within the precincts of the castle of Dover : of gateways, as at Lincoln. It is much to be regretted that the ancient Roman gateways, which existed in the city of Canterbury till within the last century, should have been destroyed, and that a similar fate should have befallen the old east gate of Chester, which is said

af these an account appears in the 22nd vol. of the Archæologia.

b Tunc montibus arduis et si qua cle- menter accedi poterant in modum valli saxa præstruit. Ann. Lib. xii. 
to have been Roman, though in the twelfth century it appears to have been cased over with the masonry of that period, as the tower of Dover was in the fifteenth century.

Independent of these, other fragments of Roman masonry are occasionally brought to light in the foundations of villas when such are discovered, and fragments of the plaster which covered the walls exhibit remains of painting either in fresco or distemper.

The regularity observable in the works of the Romans, deviated from only occasionally, when some particular circumstance required it, may be in a peculiar manner noticed in their mixed masonry of brick and stone, which it was their general plan to adopt even in districts abounding with stone; plain and simple stone masonry, without any admixture of brick, being apparently very rare exceptions to their general rule.

We have one of the many examples of this mixed kind of masonry in the multangular tower called the Pharos, situate within the precincts of the castle at Dover, for though in the fifteenth century the exterior walls of this tower were recased with flint masonry, many of the original windows blocked up, and the upper part probably added, the main body of the structure is still of undoubted Roman construction. Whereever the outer casing is worn away, or has been removed by violence, the walls exhibit the usual mode of Roman building, with the material of the district; in this case with tufa or stalactite, brought perhaps from the opposite coast of France, and flint, with layers of large flat Roman bricks, some of them two feet long, each layer two courses deep, placed regularly and horizontally in the walls at equal intervals, or nearly so. No less than eight of these layers of brick-work are visible on the south-east side, other layers are apparently concealed by the external and subsequent casing of flint and stone, and where the casing of flint is perfect, coins of stone appear at the angles.

It is somewhat difficult to ascertain the exact character of this tower in its original state, from the changes which have subsequently taken place, the original windows having been blocked up and cased over, so that externally few vestiges of them are visible.

This tower is externally octagonal in form. Internally the space inclosed forms a square. The doorway, recently 
blocked up by a hideous mass of masonry, is on the south side, and the arch, turned and faced with a single row of large Roman bricks, springs from a kind of rude impostmoulding, somewhat resembling that of the Roman gateway at Lincoln, but this is not now visible. In the interior, the constructive features of the original Roman work were, before the entrance was closed up, far more visible and perfect than on the exterior, and the facing of the bricks was quite smooth; yet the effect of the alterations is here also plainly apparent, and the original windows, the arches of which are turned with Roman brick, have been filled up with flint masonry. Both the external as well as the internal facings of the entrance-doorway on the south side were, a few years back, when the interior could be readily examined, far from perfect. Over this doorway were two windows, one above the other, each arched with brick-work. On the east side of the tower is a rather lofty arch faced with stone, the soffit of which however appears to have been turned with brick; this probably communicated with some building adjoining. Over this arch is a window now blocked up.

To that indefatigable antiquary, Dr. Stukeley, we are indebted for plans and sections of the interior of this building as it was about a century ago. We have perhaps elsewhere more extensive remains of Roman masonry than here, but it may be doubted whether we have anywhere so curious a structure of the Roman era, or one more deserving of a minute and attentive examination. As public property, and in the custody of the government of this country, it may well be considered in the fullest sense as one of our national antiquities. Much therefore is it to be regretted that the effect of the care now taken of it is to preclude the examination of what is left.

The remains at Leicester of the ancient Roman building called the Jury wall, exhibit the like construction, being composed of rag-stone embedded in mortar, bonded at intervals with regular horizontal layers of Roman brick. The arched recesses, in the only wall of this structure which remains, are likewise soffited and faced with Roman brick. Fragments of Roman columns of the Doric order, have been found not far distant from the site of this structure, and the adjoining church of St. Nicholas appears to be in a great measure constructed from the materials. Geoffry of Monmonth mentions 
a temple of Janus existing in his time at this place, and, as far as may be ascertained from engraved representations, on comparing the present appearance of the ruins of the temple of Janus at Rome, with the remains of this building at Leicester, there exists a certain degree of similarity which is very striking.

The fragment of Roman masonry at Wroxeter, Salop, consists of a wall faced with ashlar or cut stone, with six intervening rows of Roman bricks laid horizontally, as bondingcourses, at intervals, in the following manner : first ten courses of stone, then two of brick; then eight of stone, then two of brick; then six of stone, and two of brick; six more of stone, and two of brick; and six more of stone, and two of brick; cemented together with strong mortar: this also is, I think, the portion of some structure, and not merely the fragment of a wall. It is however deserving of a minute examination.

The specimens of Roman masonry which still exist in the walls of Richborough, of Pevensey, of York, of Lincoln, of Verulam, and of other places, and in the foundations of various Roman villas, all exhibit this well-known feature, the regular and horizontal interposition of the large flat Roman bricks at intervals as bonding-courses. These bricks, however, vary much in thickness and size.

The general destruction of public edifices and churches which took place in the struggles which ensued in this country after it was finally abandoned by the Romans, and before the Saxons had obtained a mastery, are pathetically adverted to by Gildas. Bede however mentions one church, that of St. Martin, near Canterbury, as an old Roman church in existence on the arrival of St. Augustine and his companions at the close of the sixth century. Now the present church contains in no portion of the walls features of Roman construction, having been entirely rebuilt from the foundation, but with the old materials of brick and stone. The exact period of such re-edification can only be ascertained by a removal of the coating of plaster with which the walls of the chancel are covered. Some of the bricks still retain portions of the original Roman mortar, partly composed of pounded brick, adhering to them.

The Anglo-Saxons appear, as far as we can judge from the scanty remains of mixed masonry in those structures which may fairly be attributed to that people, to have made use of 
the materials procured from the ruins of pre-existing Roman buildings; they did not however work up the materials of stone and brick in the same regular and systematic mode as the Romans, but though they formed some of their arches with brick-work, they seem to have inserted bricks in the walls just as they may have come to hand, irregularly and without rule or order. This is particularly observable in the construction of the masonry of Brixworth church, Northamptonshire, supposed to be an Anglo-Saxon edifice of the seventh century. This church stands in a district abounding with stone, which is found on the spot in such quantities, that the greater part of the houses in the village are built of it, yet here we have numerous semicircular-headed arches, of a single soffit, constructed of Roman brick, and springing from massive square piers : those on the north side of the nave, the north aisle having been destroyed, are blocked up, but the facing shews the arches to have been constructed of a double row of Roman bricks. The mixed masonry of brick and stone, the latter rag, of which the walls of this church are partly composed, exhibits, not the regular disposition of bricks in courses, as in Roman work, but brick irregularly intermingled with rag. This church is perhaps the most ancient existing in this country; it has apparent marks of having had additions and alterations made to it at a very early period, and the arches constructed of brick are very numerous. It displays however no features of either Roman or Norman work, but the rude baluster shafts, one of the features of presumed Anglo-Saxon work, are found in a triple window in the tower, and in some recent excavations, when the foundation wall on the north side of the chancel was exposed, the same kind of rude square-edged string-course, found in other presumed Anglo-Saxon work, was disclosed to view. Roman remains have been discovered at this place, and the ruins of some Roman building must have supplied the materials of brick with which the arches are constructed, and which also appear, but irregularly disposed, in the walls. It ought not to escape notice that the masonry in this church has been fully brought to light by the judicious removal of the plaster which formerly concealed it. It is to be wished that the same interest was taken with the walls of St.Martin's church, Canterbury.

Whether the old church now in ruins within the precincts of the castle of Dover, and close to the Pharos, be in any part 
of Anglo-Saxon construction, of which there are certainly some apparent tokens, or only a Norman structure, may be a matter of investigation and opinion; it contains round-headed doorways and windows constructed of Roman brick, and the same material mixed with stone worked up irregularly in the walls, but this building has undergone many vicissitudes.

The church of St. Michael at St. Alban's, assumed to be the one built by Ulsinus, abbot of St. Alban's, in the tenth century, and of which the nave of the original structure, with the single soffited semicircular-headed arches springing from square massive piers, still remains, is in all probability constructed of mixed masonry of brick and stone, from the ruins of the ancient city, within the site of which it stands. Independent of one object of attraction which it contains, - in a monument of no mean sculpture, placed by a servant to the memory of his master, that master the possessor of a mind of no ordinary mould, - the interest felt in entering this church would not be diminished if the plaster was removed from the arches and piers of the nave, and the Anglo-Saxon masonry of brick and stone, if such it be, exposed to view.

Although in general the Normans do not appear to have been desirous, like the Saxons, of making use of old materials for their buildings, they nevertheless did so in cases of necessity : this is apparent in the abbey church of St.Alban's, the Norman portion of which, built by abbot Paul at the close of the eleventh century, is composed of mixed masonry, vast quantities of brick having been used. The materials were collected, as Matthew Paris informs us, by a former abbot from the ruins of the old Roman city, and here they were almost indispensable, inasmuch as the district in which it is situated affords little or no stone fit for building purposes. Such materials must otherwise have been brought from a distance. The exact disposition of the bricks in the ancient part of this edifice is not very apparent, but in all probability it is irregular.

So also in the ruins of the abbey church of St. Botolph, at Colchester, an Anglo-Norman edifice seemingly late in the style, vast quantities of Roman brick, brought from pre-existing edifices, are worked up, but, as regards the mere wall-masonry, irregularly, whilst as regards an attempt at ornament, the intersecting arcade in the west front, though formed of Roman material, is clearly in plan and disposition late Norman. 
But in the castle at Colchester, which also appears to be a late Norman structure, we may perceive an attempt made to imitate the appearance of Roman work in the regular and horizontal layers or courses of Roman brick throughout the walls at intervals, and this is perhaps the nearest approximation to Roman work in external appearance we have, but when examined closely, the number of intervening courses of stone and brick greatly differ, and do not present the same degree of proportion generally observable in Roman work ; for instance, in examining the courses upwards, from the Norman set-off, of plain stone cut sloping, of the basement, to a certain height, we find most of the courses of brick and stone to be in single and alternate layers, though sometimes we meet with two courses of brick and sometimes with two of stone, and here and there we find a row of bricks set edgewise. The stone with which the walls are externally cased is cut, but the inner portions of the walls are rubble. The basement up to the set-off exhibits fragments of brick irregularly disposed in the masonry, but no regular layers or bonding-courses, as above the set-off. The pilaster-like buttresses are constructed with cut stone at the angles of the lower portion, and with Roman brick at the angles of the upper. The walls are twelve feet in thickness. In the interior we find arches of doorways, windows, and fire-places, formed of single rows of Roman brick, with brick-work disposed in herring-bone fashion at the back of the fire-places, and circular and twisted funnels for the emission of the smoke. In a lofty partition-wall, we find at a considerable height eight rows of Roman brick set edgewise, and disposed in herring-bone fashion without any admixture of stone. These bricks if procured, as they probably were, from the ruins of some old Roman structure, do not appear, from a cursory examination, to have retained any traces of the ancient mortar adhering to them, which we frequently find to be the case where Roman materials have been worked up in structures of a much later date. Not unfrequently the Roman mortar was partly composed of pounded brick.

The windows in the castle at Colchester are small and plain semicircular-headed Norman lights, with external casings of cut stone flush with the wall, whilst the portal on the south side exhibits features of late Norman work in the facing of the architrave, which has bold round mouldings with a projecting hood-moulding. 
The bricks found in the walls of this structure vary in size both superficially as well as in thickness; this we find to be the case in most Roman work, for no certain scale of dimensions appears to have been followed in the making of their bricks: perhaps the average size may be stated to be 15 inches long by 10 inches wide, and $2 \frac{1}{2}$ inches thick, but the thickness of these bricks or tiles vary from $\frac{3}{4}$ of an inch to 3 inches.

What is called herring-bone work, is by itself no criterion of any particular era; whether it may be found in any of the rude masses of ancient British masonry, is a question still to be solved. It is found in Roman, Anglo-Saxon, and AngloNorman masonry. It has also been met with in masonry of so late a period as the fourteenth century.

Though this subject has been here treated of in a very cursory and superficial manner, and nothing has been stated but what is probably well known to many, the object is rather to call attention to the investigation of the remains of early masonry wherever they exist, not merely with regard to construction, though that is and ought to be a primary consideration, but also with regard to external appearance, so as to ascertain, if possible, whether the differences between the masonry of Roman, Anglo-Saxon, and Anglo-Norman construction, are really such as will afford us any evident marks and positive rules of discrimination.

M. H. BLOXAM. 